\title{
ELECTRICAL RESISTIVITY OF ICE FROM THE ANTARCTIC PENINSULA, ANTARCTICA
}

\author{
By John M. Reynolds* and J. G. Paren
}

(British Antarctic Survey, Natural Environment Research Council, High Cross, Madingley Road, Cambridge CB3 0ET, England)

Abstract. Georesistivity soundings have been carried out at four sites in ABstract. Georesistivity soundings have been carried out at four sites in
the Antarctic Peninsula. The objective of the work was to investigate the electrical behaviour of ice from an area where substantial melting occurs in summer and from contrasting thermal regimes. Electrical measurements made at three sites along a flow line within George VI Ice Shelf reveal that: (a) the resistivity of deep ice is similar to that of other Antarctic ice shelves,

(b) the resistivity of the ice-shelf surface, which is affected by the per-

colation and refreezing of melt water, is similar to that of deep ice and hence the ice is polar in character.

A compilation of published resistivities of deep ice from polar regions shows that the range of resistivities is very narrow $(0.4-2.0) \times 10^{5} \Omega \mathrm{m}$ between -2 and $-29^{\circ} \mathrm{C}$, irrespective of the physical setting and history of the ice. Typically, resistivity is within a factor of two of $80 \mathrm{k} \Omega \mathrm{m}$ at $-20^{\circ} \mathrm{C}$ with an activation energy of $0.22 \mathrm{eV}$. In contrast, the resistivity of surface ice at Wormald Ice Piedmont, where the ice is at $0^{\circ} \mathrm{C}$ throughout, is two orders of magnitude higher and falls at the lower end of the range of resistivities for temperate ice.

Résumé. Résistivilé électrique de la glace d l'Antarctic Peninsula, Antarctique. Des sondages de résistivité ont été effectués en quatre sites de l'Antarctic Peninsula. L'objectif de ce travail était de déterminer le comportement électrique de la glace dans une zone où existe une fonte estivale substantielle ainsi que des régimes thermiques contrastés. Des mesures électriques effectuées en trois sites le long d'une ligne de courant sur le George VI Ice Shelf montrent que:

(a) la résistivité de la glace en profondeur est semblable à celle des autres shelfs antarctiques,

(b) la résistivité de la glace à la surface de la glace du shelf, qui est soumise à la percolation et au regel de l'eau de fusion, est semblable à celle de la glace en profondeur et donc la glace a un caractère polaire.

Une compilation des résistivités publiées pour la glace profonde des

\section{OBJECTIVES, INSTRUMENTATION, AND ANALYSIS}

The objective of the work was to investigate the electrical structure of an ice shelf along a flow line in an area where substantial surface melting occurs in summer. Apparent resistivity profiles were obtained at three sites along a flow line of Goodenough Glacier which crosses George VI Ice Shelf at lat. $72^{\circ} \mathrm{S}$. (Fig. 1). The area is a percolation/ soaked zone with a $10 \mathrm{~m}$ ice temperature of $-10^{\circ} \mathrm{C}$ (Reynolds, 1981[a]). To provide a comparison with the ice shelf, a profile was obtained at an airstrip $5 \mathrm{~km}$ west of Rothera station, Adelaide Island (lat. $67^{\circ} 34^{\prime}$ 'S., long. $68^{\circ} 08^{\prime}$ 'W.), a flat site at the head of the accumulation area of Wormald Ice Piedmont, where the ice is close to its melting point. All resistivity measurements were carried out in summer with surface conditions given in Table I.

A standard Schlumberger four-electrode configuration was used. Current was provided by a bank of up to six $90 \mathrm{~V}$ dry cells. The electrodes were stainless steel tubes $1 \mathrm{~m}$ long and $19 \mathrm{~mm}$ in outside diameter. The potential and current were monitored by Keithley $602 \mathrm{~B}$ electrometers and output to a Minigor $520 \mathrm{XY}-\mathrm{Yt}$ chart recorder to display the mutual decay of voltage and current. The decay is linear in agreement with Ohm's law and determines a resistance $R$ from which an apparent resistivity $\rho_{a}$ of the medium can be computed. The well-known relationship for the Schlumberger array is

*Present address: Department of Environmental Sciences, Plymouth Polytechnic, Drake Circus, Plymouth, Devon PL4 8AA, England. régions polaires montre que le domaine des résistivités est très réduit $(0,4-2,0) \times 10^{5} \Omega \mathrm{m}$ entre -2 et $-29^{\circ} \mathrm{C}$, quelles que soient la situation physique et l'histoire de la glace. Particulièrement, la résistivité est proche à un facteur deux près de $80 \mathrm{k} \Omega \mathrm{m}$ à $-20^{\circ} \mathrm{C}$ avec une énergie d'activation de $0,22 \mathrm{eV}$. Par contre, la résistivité de la glace de surface sur le Wormald Ice Piedmont, où la glace est à $0^{\circ} \mathrm{C}$ partout, est de deux ordres de grandeur plus élevée et se situe à la limite inférieure du domaine des résistivités de la glace tempérée.

Zusammenfassung. Elektrischer Widerstand von Eis der Antarctic Peninsula, Antarktika. An vier Stellen auf der Antarctic Peninsula wurden elektrische Widerstandssondierungen vorgenommen. Das Ziel dieser Arbeit war die Untersuchung des elektrischen Verhaltens von Eis aus einem Gebiet, wo im Sommer wesentliche Abschmelzung auftritt, und aus Bereichen mit unterschiedlichen Wärmehaushalten. Elektrische Messungen an drei Stellen längs einer Stromlinie innerhalb des George VI Ice Shelf ziegen, dass

(a) der Widerstand tiefen Eises ähnlich dem auf anderen antarktischen Schelfeisen ist,

(b) der Widerstand der Schelfeisoberfläche, auf der sich Sickervorgänge und Wiedergefrieren von Schmelzwasser auswirken, ähnlich dem des tiefen Eises ist und folglich das Eis dort polaren Charakter besitzt.

Eine Zusammenstellung veröffentlichter Widerstandswerte für tiefes Eis aus Polargebieten zeigt, dass sich die Widerstände sehr nahe an den Bereich von $(0,4-2,0) \times 10^{5} \Omega \mathrm{m}$ zwischen -2 und $-29^{\circ} \mathrm{C}$ halten, unabhängig vom Setzungszustand und von der Vorgeschichte des Eises. Typisch für den Widerstand ist eine Schwankung von $80 \mathrm{k} \Omega \mathrm{m}$ bei $-20^{\circ} \mathrm{C}$ und einer Aktivationsenergie von $0,22 \mathrm{eV}$ mit dem Faktor 2. Im Gegensatz dazu ist der Widerstand von Oberflächeneis im Wormald Ice Piedmont, wo die Eistemperatur durchwegs $0^{\circ} \mathrm{C}$ beträgt, um zwei Grössenordnungen höher; er liegt damit an der unteren Grenze des Widerstandsbereiches für temperiertes Eis.

$$
\rho_{a}=\frac{\pi a^{2}}{b}\left(1-\frac{b^{2}}{4 a^{2}}\right) R
$$

where $2 \mathrm{a}$ and $\mathrm{b}$ are the separations of the current and voltage electrodes respectively. Full details of the data reduction and analysis are given by Reynolds (1982).

The apparent-resistivity profiles have been interpreted using a computer program based on Ghosh's convolution method (Ghosh, 1971). The program synthesizes an apparent-resistivity profile for an n-layered model in which the variables are layer thickness and resistivity. Model profiles were compared with the field data and the variables adjusted by trial and error to obtain an acceptable match.

\section{RESISTIVITY OF GEORGE VI ICE SHELF}

Values of apparent resistivity are listed in Table II and illustrated in Figure 2. For each profile the data are shown with standard deviations. Superimposed are the synthesized curves which fit the data well. At the foot of each figure are the layer models used to generate the appropriate curves. In each model, the bottom layer is chosen to represent cold water of oceanic salinity and resistivity $0.3 \Omega \mathrm{m}$.

Profiles for RJ and RK shown in Figure $2 a$ and $b$ have been published previously and discussed in detail by Reynolds (1982). The small variation of resistivity found with depth is due to the ice shelf 


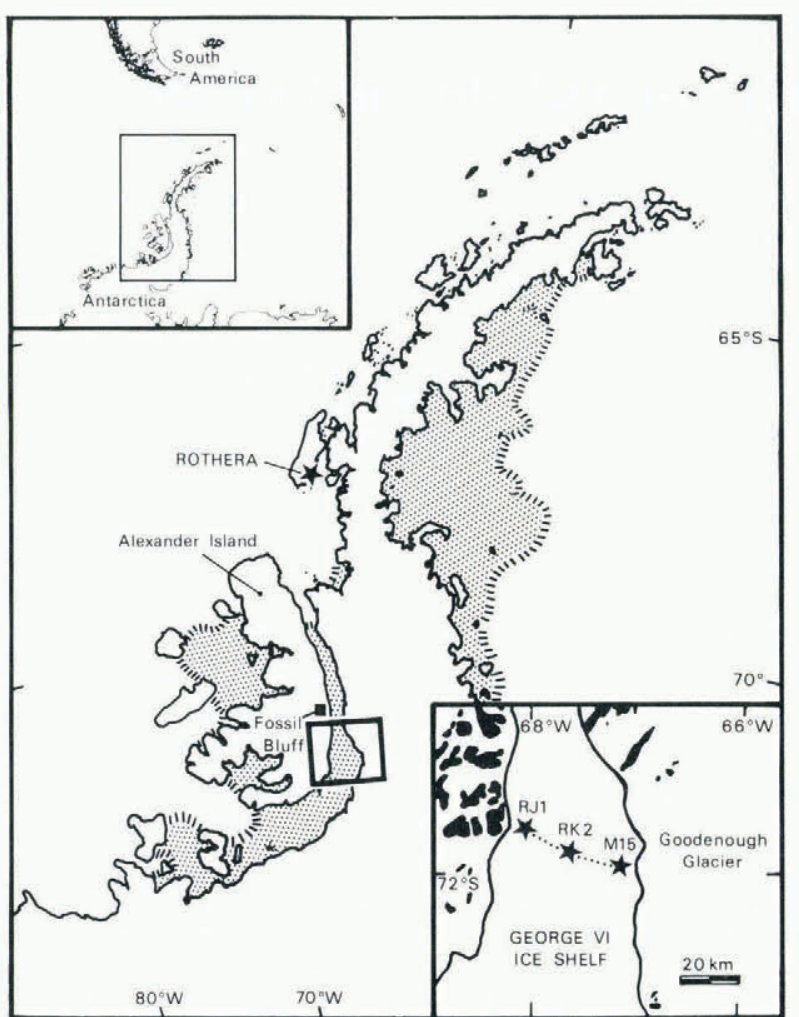

Fig. 1. Map of the Antarctic Peninsula showing research sites.
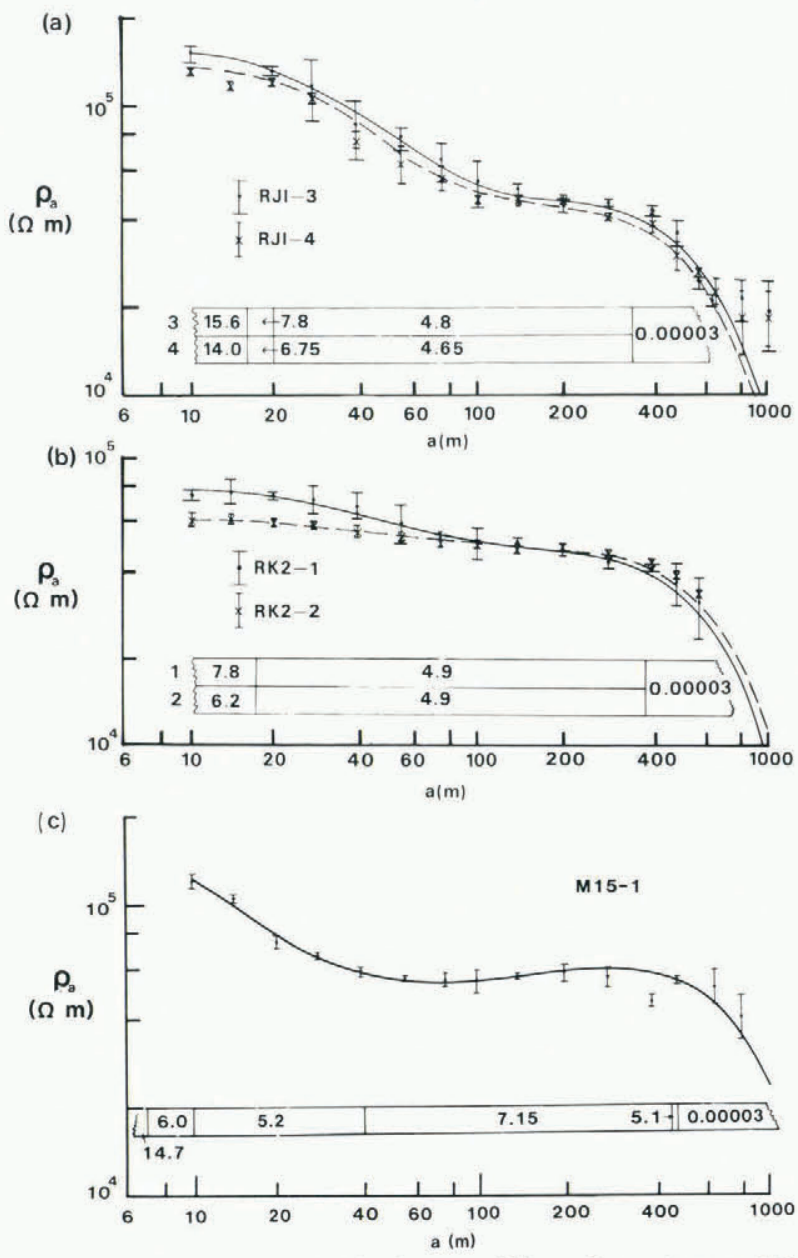

Fig. 2. Apparent resistivity profiles from George VI Ice Shelf. Model resistivities are in units of $10 \mathrm{k} \Omega \mathrm{m}$, and plotted against depth within the ice sheet.

TABLE I. DETAILS OF SITES AT WHICH RESISTIVITY SOUNDINGS WERE UNDERTAKEN

\begin{tabular}{|c|c|c|c|c|c|c|}
\hline Site & Array & or 1 * & $\begin{array}{c}\text { Maximum } \\
\text { a } \\
\mathrm{m}\end{array}$ & $\begin{array}{l}\text { Ice thickness } \\
\text { Radar sounding } \\
\mathrm{m}\end{array}$ & $\begin{array}{l}\text { from } \\
\text { Reference }\end{array}$ & Remarks \\
\hline & RJ1-3 & & 1000 & $300 \pm 20$ & 1 & Surface hard and dry \\
\hline & RJ1-4 & & 1000 & $330 \pm 10$ & 2 & $\begin{array}{l}\text { Slushy surface over- } \\
\text { lying thin }(2-5 \mathrm{~cm}) \\
\text { crust of frozen firn }\end{array}$ \\
\hline George VI & RK2-1 & & 640 & $316 \pm 20$ & 1 & \multirow{2}{*}{$\begin{array}{l}\text { Warm weather, surface } \\
\text { temperatures } 0^{\circ} \mathrm{C} \text { with } \\
\text { frequent flurries of } \\
\text { wet snow }\end{array}$} \\
\hline \multirow[t]{2}{*}{ Ice Shelf } & RK2-2 & & 560 & $363 \pm 10$ & 2 & \\
\hline & M15-1 & & 800 & $\begin{array}{l}400 \pm 20 \\
432 \pm 10\end{array}$ & $\begin{array}{l}1 \\
2\end{array}$ & Surface hard and dry \\
\hline $\begin{array}{l}\text { Rothera airstrip } \\
\text { Adelaide Island }\end{array}$ & RA-1 & & 390 & $173 \pm 7$ & 3 & $\begin{array}{l}\text { Surface dry; ice } \\
\text { temperature } 0^{\circ} \mathrm{C}\end{array}$ \\
\hline
\end{tabular}

References: 1: Smith (1972); 2: Bishop and Walton (1981); 3: S.N. Stephenson (personal communication) * $\|$ or $\perp \begin{aligned} & \text { refer to the orientation of the array either parallel or perpendicular to the local ice flow line. } \\ & \text { Maximum a is the maximum current-electrode half-separation. }\end{aligned}$ 
TABLE II. APPARENT RESISTIVITIES ON GEORGE VI ICE SHELF

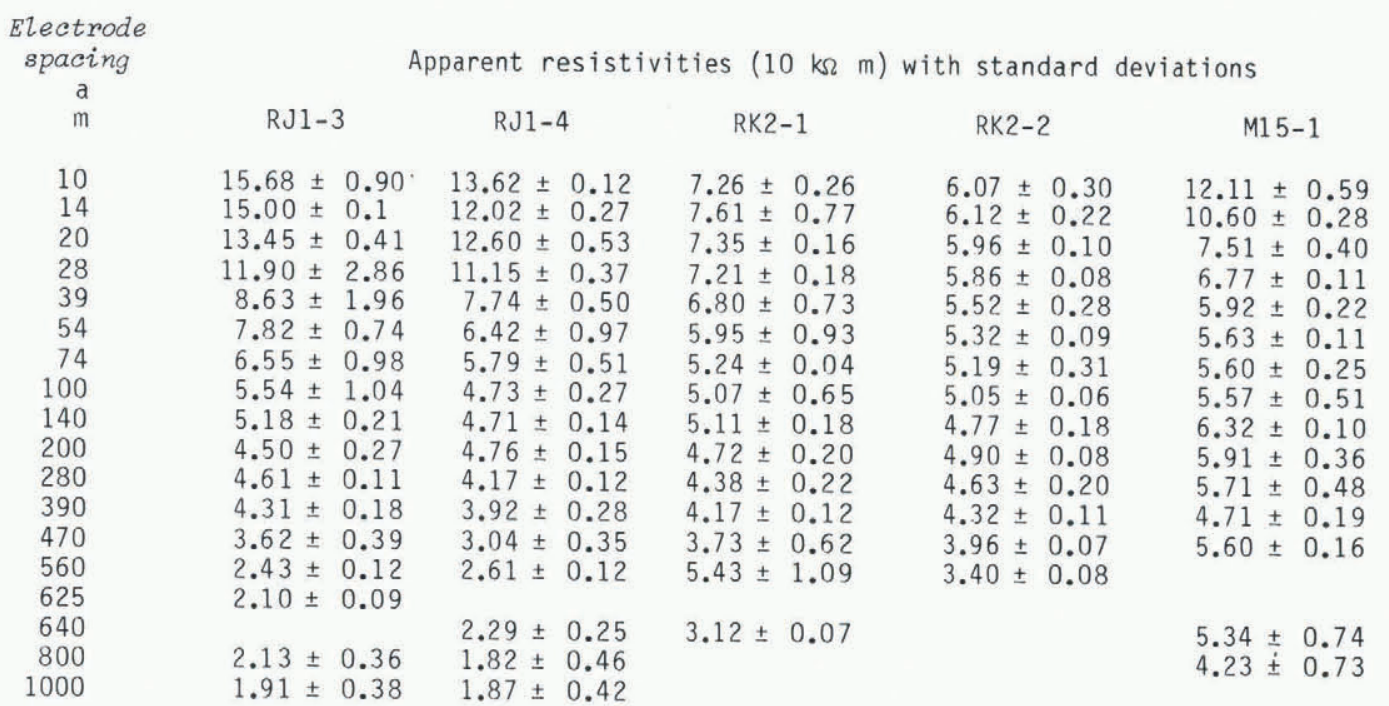

having only a narrow range of temperature and nearly constant density. The percolation and refreezing of melt water ensured high densities near the surface. In addition, ice of the same density, whether formed by compaction or percolation and refreezing, has the same resistivity (Reynolds and Paren, 1980). The essential difference between the model for M15 (Fig. 2c) and those for RJ and RK is that the bulk of the ice shelf has a resistivity value of $71.5 \mathrm{k} \Omega \mathrm{m}$ compared to $48 \mathrm{k} \Omega \mathrm{m}$ further down-stream along the flow line. Within an ice shelf near its grounding line, ice may be found at a colder temperature than at the glacier surface, but this cold sink will be progressively eliminated whilst the ice is afloat and warmed by the air and the sea (Paterson, 1981). M15 is only $10 \mathrm{~km}$ from the grounding line and has been afloat for just 14 years (based on data from Bishop and Walton, 1981). In such a short period of time, only the lowermost portion of the total ice column reflects changes in basal conditions since passing the grounding line. For $\mathrm{M15}$, the characteristic thickness $\mathrm{Z}$ affected by heat flow at the base of the ice shelf is around $45 \mathrm{~m}$ as calculated from heat-flow theory (where $Z=2 / K_{j} t$, $t$ being the time since crossing the grounding line and $K_{j}$ the thermal diffusivity $\left.=36 \mathrm{~m}^{2} \mathrm{a}^{-1}\right)$. Thus, except in the basal region, M15 has a temperature structure determined by its previous history when grounded. Changes in temperature within the ice shelf seem the most likely explanation for the lateral trend in resistivity while the ice flows from M15 to RJ in 155 years. However, an unrealistically high degree of warming ( 9 deg) is needed to convert ice of resistivity $72 \mathrm{k} \Omega \mathrm{m}$ to $50 \mathrm{k} \Omega \mathrm{m}$ if the activation energy for the resistivity of ice is $0.22 \mathrm{eV}$ as is suggested later. It is not known how so much warming could occur or by what other mechanism the $72 \mathrm{k} \Omega \mathrm{m}$ resistivity could decrease to $50 \mathrm{k} \Omega \mathrm{m}$ as the ice flows westwards.

The temperature regime of an ice shelf is strongly influenced by the rate of melting (or freezing) $\dot{m}$ at its base. For M15, Bishop and Walton (1981) estimated $\dot{m}$ to be $6 \mathrm{~m} \mathrm{a}^{-1}$. A temperature gradient in the basal region can be accommodated in the model for M15 by introducing a $20 \mathrm{~m}$ thick layer with a resistivity of $51 \mathrm{k} \Omega \mathrm{m}$ at the ice-shelf base. The introduction of thin basal layers of lower resistivity ice would not seriously perturb the fitting of profiles RK and RJ. A more sophisticated analysis for site RK has been provided by $\mathrm{S}$. Shabtaie based on a computer program developed by Bentley (1977). The analysis permits resistivity to vary continuously with depth through an assumed dependence of resistivity on density and on temperature. In principle a temperature profile and hence the heat flow at the base may be verified from the resistivities. Shabtaie deduced a basal melt rate of $1 \mathrm{~m} \mathrm{a}^{-1}$ at RK. An independent calculation based on similar assumptions gave minimum melting rates of $1 \mathrm{~m} \mathrm{a}^{-1}$ at RK and $2 \mathrm{~m} \mathrm{a}^{-1}$ at RJ (Reynolds, 1982). Aspects of the sites are far from ideal for either calculation. By necessity, horizontal advection has been disregarded and the temperature dependence of resistivity, although poorly known above $-10^{\circ} \mathrm{C}$ was given an activation energy of $0.15 \mathrm{eV}$. Both factors militate against a reliable determination of melt rate, although other evidence suggests $1-2 \mathrm{~m} \mathrm{a}^{-1}$ is the norm for the ice shelf (Potter and others, 1984).

Figure 3 shows the structure of the ice shelf using data from the georesistivity profiles, radio echo-sounding, and ground survey. The surface layers at RJ and $\mathrm{M} 15$ are consistent with a top layer with a resistivity of 140-156 $\mathrm{k} \Omega \mathrm{m}$, underlain by a layer common to the three sites with a resistivity in the range $60-78 \mathrm{k} \Omega \mathrm{m}$. The higher resistivity layer is thought to be firn through which some melt-water percolation has occurred. The lower layer probably has a higher density and on the evidence from site RK appears to be associated with firn which has been

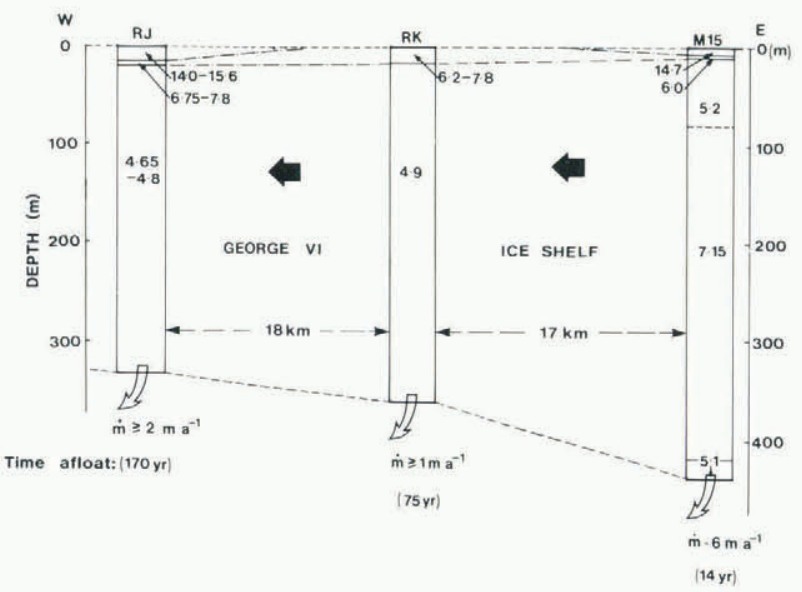

Fig. 3. Resistivity structure through George VI Ice Shelf along a flow line. Resistivities are in units of $10 \mathrm{k} \Omega \mathrm{m}$, and plotted against depth within the ice sheet. 
saturated by melt water and refrozen. At RK the presumed drier firn layer is absent, and the second layer is appreciably thicker than elsewhere. The three sites lie along a flow line parallel to long undulations formed as a result of ice movement, and it was intended to locate all resistivity arrays on the crest of one undulation. However, RK was inadvertently located to one side, closer to an adjacent trough. In such troughs the firn becomes saturated by melt water and the ice layers are thicker because melt-water lakes tend to form there (Reynolds, 1981[b]).

\section{RESISTIVITY OF WORMALD ICE PIEDMONT}

Values of apparent resistivity are listed in Table III and illustrated in Figure 4. The profile confirms that the glacier is land-based and has a lower resistivity than the underlying bedrock. Three layermodels generated nearly identical profiles. Two models ( $A$ and $B$ ) were developed independently of other data, and provided a total ice thickness of $150 \pm 10 \mathrm{~m}$. The third model (C) was constrained to an ice thickness of $170 \mathrm{~m}$ obtained from radio echo-sounding. The resistivities of the surface ice layer and of the bedrock were common to al1 three models, $3.5 \mathrm{Mr} \mathrm{m}$ and $10 \mathrm{M} \mathrm{m}$ respectively. The 1 ithology of nunataks close by is known: Andean intrusives such as gabbrogranodiorite predominate along with uncorrelated (?) Upper Jurassic volcanic and sedimentary rocks (Dewar 1970). Rocks such as these have resistivities of the

TABLE III. APPARENT RESISTIVITIES AT ROTHERA AIRSTRIP ON WORMALD ICE PIEDMONT

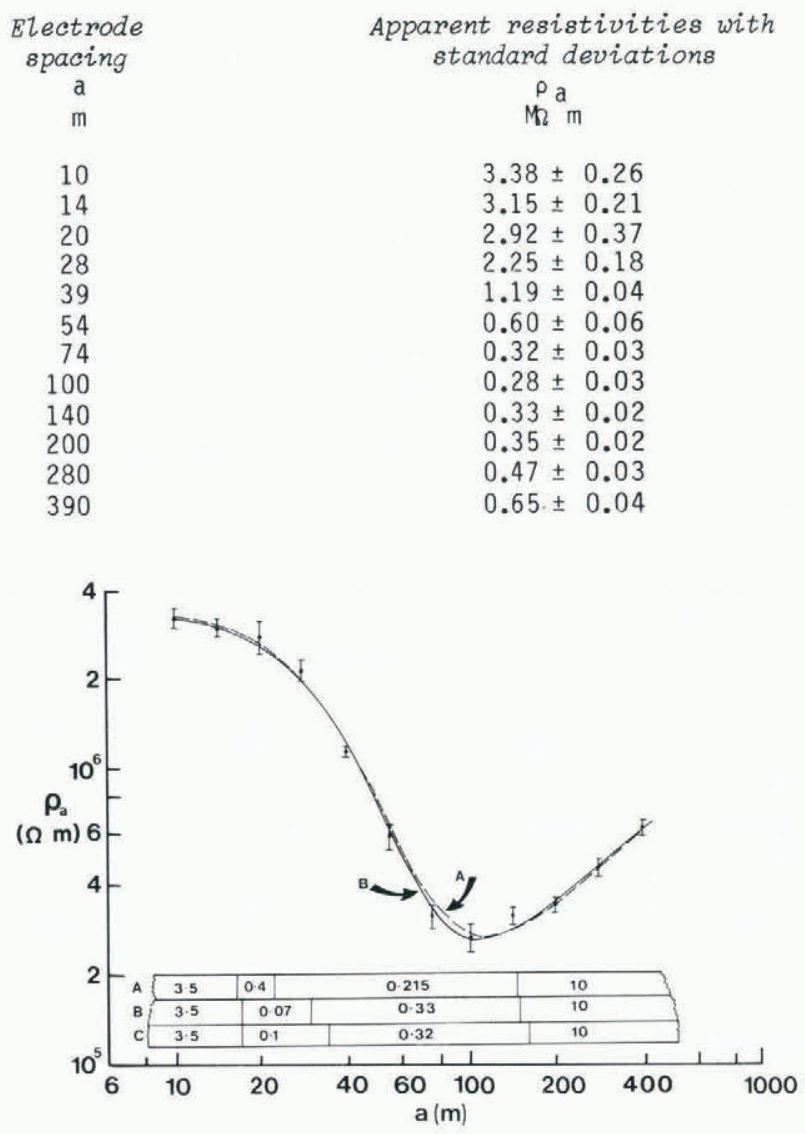

Fig. 4. Apparent resistivity profile for Wormald Ice piedmont. The curves $A$ and $B$ are computed profiles derived from the respective models (depicted in units of $M \Omega m$ beneath the graphs). Curve $C$ is not plotted. It closely coincides with $A$ and $B$. order of 1-100 M m (Telford and others, 1976), spanning the range deduced for the bedrock. The resistivity of the surface ice layer $(3.5 \mathrm{M} / \mathrm{m})$ is a factor of twenty higher than that of any surface layer on George VI Ice Shelf. It lies within the range of resistivities for the surface layers of temperate glaciers (0.3-14 M m) reported by Röthlisberger (1967) and Röthlisberger and Vögtli (1967). Thus the surface resistivity is compatible with the thermal reg$i$ me of an accumulation region of a temperate glacier. The resistivity of the lower ice layers $(0.07$ to $0.4 \mathrm{M} \mathrm{m}$ ) of Wormald Ice Piedmont is more difficult to interpret. According to Röthlisberger and Vögt $1 i$ (1967) the range $10-120 \mathrm{M} \mathrm{m}$ is characteristic of the resistivity of deep ice in temperate glaciers. Having collected together data from many georesistivity surveys they noted "a certain tendency seems to exist in the distribution of resistivities, so that the highest values occur in the oldest ice, the lowest in young ice and below ice falls". Glen and others (1977) saw this as the result of a reduction of impurities down-glacier by recrystallization processes and by melt water purging and washing out impurities. On Wormald Ice Piedmont, the resistivity profile seems to indicate that the concentration of impurities increases with depth with the older ice being less resistive than the surface. However, this explanation is conjectural in the absence of deep ice cores and precise temperature measurements. Wormald Ice Piedmont, if temperate, is the least resistive of any temperate glaciers so far studied electrically.

\section{COMPARISON OF ICE RESISTIVITIES IN POLAR REGIONS}

Georesistivity investigations at 27 sites on glaciers in the Arctic and Antarctic have been compiled in Table IV. From this compilation, measurements of the resistivity of ice from depths greater than $100 \mathrm{~m}$ have been plotted in Figure 5 against the estimated in situ temperature. This updates two earlier presentations of the then available data (fig. 2 of Paren, 1973 and fig. 4 of Glen and Paren, 1975). Three lines are superimposed on Figure 5. The first is the regression line for the field data (dashed). This 1 ine has an activation energy of $0.22 \pm 0.03 \mathrm{eV}$ and gives an average resistivity of $55 \mathrm{k} \mathrm{m}$ at $-10^{\circ} \mathrm{C}, 80 \mathrm{k} \Omega \mathrm{m}$ at $-20^{\circ} \mathrm{C}$, and $350 \mathrm{k} \Omega \mathrm{m}$ at $-52^{\circ} \mathrm{C}$. The regression line is unaltered even if the

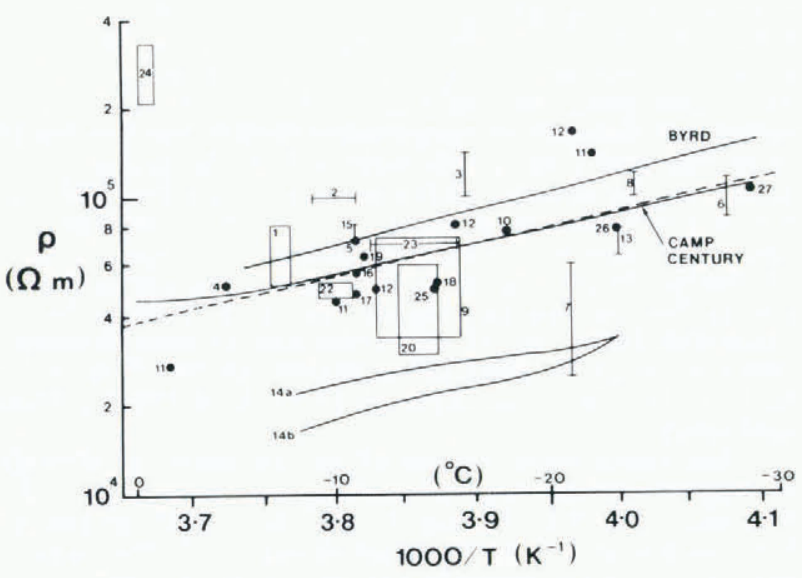

Fig. 5. Resistivity of ice. Mean values from georesistivity sounding of ice at $100 \mathrm{~m}$ or deeper are plotted with estimated uncertainties against the estimated layer temperature. Source of data is Table IV. Laboratory measurements on ice cores examined over a range of temperatures are shown by continuous lines. The regression $l i n e$ for the data is given by a dashed line. 
TABLE IV. SOURCE OF DATA FOR FIGURE 5

No. Reference

1 Andrieux (1970)

2 Andrieux (1970)

3 Andrieux (1970)

4 Andrieux (1970)

5 Clark and others (1969)

6 Hochstein (1965)

7 Hochstein (1965)

Meyer \& Röthlisberger (1962)

5 Thyssen \& Shabtaie (1983)

6 Thyssen \& Shabtaie (1983)

7 Thyssen \& Shabtaie (1983)

9 Vögtli (1967)

10 Vögtli (1967)

11 Hochstein (1967)

12 Hochstein (1967)

13 Bentley (1977)

$14+$ Bentley (1979)

15* Shabtaie \& Bentley (1979)

16* Shabtaie \& Bentley (1979)

17 * Shabtaie \& Bentley (1979)

18* Shabtaie \& Bentley (1979)

19* Shabtaie \& Bentley (1979)

20 Hochstein \& Risk (1967)

21 Thyssen \& Shabtaie (1983) $x x$

22 Reynolds (1982)

23 This paper

24 This paper
Location

Arctic sites

Observatory Glacier, Baffin Island

Penny Ice Cap, Baffin Island

Meighen Island ice cap

TUTO, Greenland

Paris Gletscher, Greenland

Station Centrale, Greenland

Point Nord, Greenland

Camp Century, Greenland

Camp VI, Greenland

T11, Greenland

Crête, Greenland

Sverdrup Glacier, Devon Island

Ice cap station, Devon Island

Antarctic sites

Ross Ice Shelf

Roosevelt Island

Ross Ice Shelf (Base Camp)

Ross Ice Shelf (J9)

Ross Ice Shelf (Q13)

Ross Ice Shelf (C16)

Ross Ice Shelf (M14)

Ross Ice Shelf (019)

Ross Ice Shelf (011)

McMurdo Ice Shelf, bore-hole log

(site 207D)

Dome $C$

George VI Ice Shelf (RJ and RK)

George VI Ice Shelf (M15)

Wormald Ice Piedmont

+ Data taken from figs 7 and 9 of Bentley (1979). N.B. the absolute value of resistivity may be in error by a factor of two or more.

* Resistivity value computed by J.M. Reynolds from apparent resistivity profiles.

$x x$ Not plotted in Fig. 5. Dome $C$ has a resistivity of $350 \mathrm{k} \Omega \mathrm{m}$ at $-52^{\circ} \mathrm{C}$.

Dome C data of Thyssen and Shabtaie (1983) are excluded from the analysis. Reviewing data from just six sites, Thyssen and Shabtaie (1983) suggest that the resistivity of ice is constrained in an even narrower band: $67 \pm 7 \mathrm{k} \Omega \mathrm{m}$ at $-20^{\circ} \mathrm{C}$ and activation energy $0.25 \mathrm{eV}$. Three results have been omitted from the present regression; results $14 \mathrm{a}$ and $14 \mathrm{~b}$ since they may be in error by a factor of two or more (Bentley, 1979) and result 24 from Wormald Ice Piedmont since its thermal regime is temperate. The other lines are the deduced d.c. resistivity for two deep ice cores measured in the laboratory over a wide temperature and frequency range using a simple guarded-electrode dielectric cell. In such an arrangement electrode interface effects dominate the low-frequency response and the assessment of a true d.c. resistivity from a.c. measurements is difficult. Nevertheless, Figure 5 shows that the ice-core data are in accord with the field measurements. The more resistive ice core is from Byrd Station, Antarctica (Fitzgerald and Paren, $1975)$ which was incorrectly plotted in figure 4 of Glen and Paren (1975). The other is the mean from four sets of data from Camp Century, Greenland (Paren, 1973). The Camp Century data indicate that resistivity is independent of temperature above $-10^{\circ} \mathrm{C}$. At lower temperatures it has an activation energy of $0.21 \mathrm{eV}$, similar to the value of $0.22 \mathrm{eV}$ for the regression line and $0.23 \mathrm{eV}$ for the Byrd Station data. The most reliable data in Figure 5 should be those determined by field measurements over ice shelves of known thickness due to their simple geometry and known sub-ice environment. There is particularly close numerical agreement between the resistivities of ice from George VI Ice Shelf (Results 22-23 and Fig. 2) and from Ross Ice Shelf (Results 13, 15-19), even though the upper layers of George VI Ice Shelf are formed principally by local percolation and refreezing of melt water rather than by compaction, the usual process at lower surface temperatures. In contrast a major modification to the electrical behaviour of part of the Byrd ice core was found by Fitzgerald and Paren (1975) after melting it and refreezing it in the laboratory. However, they examined the samples only hours after refreezing them, whereas the ice layers near the surface of George VI Ice Shelf are much older. It is clear that experiments are required to investigate time-dependent processes in natural ice. The sites at which the resistivity soundings have been carried out vary greatly in their physical setting. Total impurity concentration, altitude, grainsize, crystal fabric, accumulation rate, incidence of melting, age, and strain history can all be different. We suggest that these factors cannot be strongly linked to resistivity. Maccagnan (unpublished) believes that in the polar regions the narrow range of resistivity is a result of the fairly uniform deposition of Aitken nuclei which consist of hydrated sulphuric acid. The sulphate ion, $\mathrm{SO}_{4} 2-$ is a major impurity within continental ice sheets, though nitrate $\left(\mathrm{NO}_{3}{ }^{-}\right)$may also be important. The level of background "excess sulphate" is determined by the accumulation rate. The range is probably 15 to 50 
p.p.b. at the Arctic sites and 25 to 50 p.p.b. at the Antarctic sites of Table IV (Herron, 1982). In fact, it is difficult to estimate the sulphate concentration for deep ice from any of the ice-shelf sites, because the snow will have been deposited far away. No resistivity-sulphate dependence is discernible from within the scatter of Figure 5 . However, in polar ice sheets, internal reflections have been detected by radio echo-sounding (Robin and others, 1969) and are thought to be due to elevated concentrations of volcanogenic sulphate (Millar, 1982). Such sulphate-rich layers have also been associated with peaks in the static electrical conductivity as measured in polar ice cores (Hammer, 1980).

Some of the scatter in Figure 5 may result from inaccurate interpretation of profiles in ambiguous terrain and incorrect estimates of the relevant temperature. In the temperature range $-10^{\circ} \mathrm{C}$ to $-25^{\circ} \mathrm{C}$ the true resistivity of deep polar ice averaged over many years of deposition varies by less than a factor of two from the regression line of Figure 5 . The variation at a given temperature is small by comparison with the three orders of magnitude that separate the most resistive temperate ice from the non-temperate ice of the polar regions.

\section{CONCLUSION}

Georesistivity measurements made along a flow line on George VI Ice Shelf have established that throughout the thickness of the ice shelf the ice behaves in a comparable way to that formed in colder polar environments. This is an important finding since the flow line is in a transitional percolation-soaked zone and melt water percolates and refreezes in the firn a process which is absent at similar in situ temperatures deep in dry polar glaciers where similar resistivities are measured. A compilation of all available data show that polar ice has a well defined resistivity irrespective of the physical setting and history of the ice. Typically the resistivity is within a factor of two of $80 \mathrm{k} \Omega \mathrm{m}$ at $-20^{\circ} \mathrm{C}$ with an activation energy of $0.22 \mathrm{eV}$. In polar regions, only temperate glaciers such as Wormald Ice Piedmont and Glacier Cook on Îles Kerguelen (Andrieux, 1970) have resistivities which deviate from the now welldocumented values for polar ice.

\section{ACKNOWLEDGEMENTS}

We are grateful to S.J. Artis and J.A. Jewell who assisted with field work on George VI Ice Shelf, and to J.L. Wade who helped with computing.

\section{REFERENCES}

Andrieux, P. 1970, Les méthodes électriques de prospection appliquées à l'étude de la glace et des glaciers. Resultats obtenus de 1962 à 1965. CNFRA (Comité National Francais des Recherches Antarctiques), No. 24.

Bentley, C.R. 1977. Electrical resistivity measurements on the Ross Ice Shelf. Journal of Glaciology, Vol. 18, No. 78, p. 15-35.

Bentley, C.R. 1979. In-situ measurements of the activation energy for d.c. conduction in polar ice. Journal of Glaciology, Vol. 22, No. 87, p. 237-46.

Bishop, J.F., and Walton, J.L.W. 1981. Bottom melting under George VI Ice Shelf, Antarctica. Journal of Glaciology, Vol. 27, No. 97, p. 429-47.

Clark, M.C., and others. 1969. Ice-resistivity measurements on Paris Gletscher, East Greenland, by M.C. Clark, M.H. Key, and G.J. Pert. Journal of Glaciology, Vol. 8, No. 54, p. 369-73.

Dewar, G.J. 1970. The geology of Adelaide Island. British Antarctic Survey. Scientific Reports, No. 57.

Fitzgerald, W.J., and Paren, J.G. 1975. The dielectric properties of Antarctic ice. Joumal of Glaciology, Vol. 15 , No. 73 , p. 39-48.
Ghosh, D.P. 1971. Inverse filter coefficients for the interpretation of apparent resistivity standard curves for a horizontally stratified earth. Geophysical prospecting, Vol. 19, No. 4, p. 769-75.

Glen, J.W., and Paren, J.G. 1975. The electrical properties of snow and ice. Journal of Glaciology, Vo 1. 15, No. 73, p. 15-38.

Glen, J.W., and others. 1977. Water at grain boundaries: its role in the purification of temperate glacier ice, [by] J.W. Glen, D.R. Homer, and J.G. Paren. [Union Géodésique et Géophysique Intemationale. Association Internationale des Sciences Hydrologiques. Commission des Neiges et Glaces.] Symposium Isotopes et impuretés dans les neiges et glaces. Actes du colloque de Grenoble, août /septembre 1975, p. 263-71. (IAHS-AISH Publication No. 118.)

Hammer, C.U. 1980. Acidity of polar ice cores in relation to absolute dating, past volcanism, and radio-echoes. Journal of Glaciology, Vol. 25, No. 93, p. 359-72.

Herron, M.M. 1982. Impurity sources of $\mathrm{F}^{-}, \mathrm{Cl}^{-}, \mathrm{NO}_{3}^{-}$, and SO $2-$ in Greenland and Antarctic precipitation. Journat of Geophysical Research, Vol. 87, No. C4, p. 3052-60.

Hochstein, M.P. 1965. Elektrische Widerstandsmessungen auf dem grönländischen Inlandeis. Meddelezser om Gronland, Bd. 177, Nr. 3.

Hochstein, M.P. 1967. Electrical resistivity measurements on ice sheets. Journal of Glaciology, Vol. 6, No. 47 , p. 623-33.

Hochstein, M.P., and Risk, G.F. 1967. Geophysical measurements on the McMurdo Ice Shelf, Antarctica, during 1965-66. New Zealand. Dept. of Scientific and Industrial Research. Geophysical Survey, Geophysics Division. Report No. 47.

Maccagnan, M. Unpublished. Contribution à l'étude des propriétés diēlectriques de la glace Antarctique, application géochimique. [Thēse de troisième cycle, Université Scientifique et Médicale de Grenoble, 1981.]

Meyer, A.U., and Röthlisberger, H. 1962. Electrical DCresistivity measurements on glacier ice near Thule, Greenland. U.S. Cold Regions Research and Engineering Laboratory. Technical Report 87.

Millar, D.H.M. 1982. Acidity levels in ice sheets from radio echo-sounding. Annals of Glaciology, Vol. 3, p. 199-203.

paren, J.G. 1973. The electrical behaviour of polar glaciers. (In Whalley, E., and others, ed. Physics and chemistry of ice: papers presented at the Symposium on the Physics and Chemistry of Ice, held in Ottawa, Canada, 14-18 August 1972. Edited by E. Whalley, S.J. Jones, L.W. Gold. Ottawa, Royal Society of Canada, p. 262-67.)

Paterson, W.S.B. 1981. The physics of glaciers. Secand edition. 0xford, etc., Pergamon Press. (Pergamon International Library.)

Potter, J.R., and others. 1984. Glaciological and oceano graphic calculations of the mass balance and oxygen isotope ratio of a melting ice shelf, by J.R. Potter, J.G. Paren, and J. Loynes. Journal of Glaciology, Vo 1. 30, No. 105, p. 161-70.

Reynoids, J.M. 1981[a]. The distribution of mean annual temperatures in the Antarctic Peninsula. British Antarctic Survey. Bulletin, No. 54, p. 123-33.

Reynolds, J.M. 1981[b]. Lakes on George VI Ice Shelf, Antarctica. Polar Record, Vol. 20, No. 128, p. 42532.

Reynolds, J.M. 1982. Electrical resistivity of George VI Ice Shelf, Antarctic Peninsula. Annals of Glaciology, Vol. 3, p. 279-83.

Reynolds, J.M., and Paren, J.G. 1980. Recrystallisation and electrical behaviour of glacier ice. Nature, Vol. 283, No. 5742, p. 63-64.

Robin, G. de Q., and others. 1969. Interpretation of radio echo sounding in polar ice sheets, by G. de Q. Robin, S. Evans, and J.T. Bailey. Philosophical Transactions of the Royal Society of London, Ser. A, Vol. 265, No. 1166, p. 437-505. 
Röthlisberger, H. 1967. Electrical resistivity measurements and soundings on glaciers: introductory remarks. Journal of Glaciology, Vol. 6, No. 47, p. 599-606. Röthl isberger, H., and Vögtli, K. 1967. Recent D.C. resistivity soundings on Swiss glaciers. Joumal of Glaciology, Vol. 6, No. 47, p. 607-21.

Shabtaie, S., and Bentley, C.R. 1979. Investigation of bottom mass-balance rates by electrical resistivity soundings on the Ross Ice Shelf, Antarctica. Journal of Glaciology, Vol. 24, No. 90, p. 331-43.

Smith, B.M.E. 1972. Airborne radio echo sounding of glaciers in the Antarctic Peninsula. British Antarctic Survey. Scientific Reports, No. 72.

Telford, W.M., and others. 1976. Applied geophysics, by W.M. Telford, L.P. Geldart, R.E. Sheriff, and D.A. Keys. Cambridge, Cambridge University Press. Thyssen, F., and Shabtaie, S. 1983. Durchführung und Auswertung geoelektrischer Messungen grosser Auslage bei Dome C, Ostantarktis. Polarforschung, Jahrg. 53, $\mathrm{Nr}, 1$, p. 1-10.

Vögtli, K. 1967. D.C. resistivity soundings on Devon Island, N.W.T., Canada. Journal of Glaciology, Vol. 6, No. 47 , p. 635-42.

MS. received 14 November 1983 and in revised form 15 March 1984 